\title{
Study on Cooperative Teaching Mode of Digital Publishing Courses in the Internet Era
}

\author{
Yongxin Liu \\ Media and Mathematics \& Physics School \\ Jilin Engineering Normal University \\ Changchun, China 130000
}

\begin{abstract}
With continuous improvement of the economy in China, the scientific and technical level improves accordingly. The digital publishing course is one of key points in the education reform of colleges and universities in China. With the arrival of the Internet era, the cooperative teaching of digital publishing courses of colleges and universities in China also has certain favorable factors. The current teaching mode of digital publishing courses fails to keep up with the industry development demands. Therefore, cultivation of a group of digital publishing talents with high quality and level will become an important power to promote the development of the industry. Based on the current teaching status of digital publishing courses of higher education institutions in China, this paper analyzes the problems existed in the teaching process of digital publishing courses and optimization methods of the cooperative teaching mode of digital publishing courses in the Internet era with the combination of the situation of the new era.
\end{abstract}

Keywords-Digital Publishing; Internet Era

\section{INTRODUCTION}

Under the background of the Internet era, the traditional publishing industry is weeding out the old publishing technology and adopting the new one. The digital publishing is the mainstream and major direction for the development of the publishing industry in the future. Different from the traditional publishing industry, the digital publishing industry has more high-quality characteristics. The digital publishing industry not only presents diversified forms but also has colorful contents. In addition, the digital publishing industry has higher requirements for personnel in the industry who not only need to have the required basic theory of text editing and editing and publishing knowledge reserves but also need to have a good knowledge of the technology of the computer major, knowledge system of new media and other emerging fields. Colleges and universities are the training cradle and output channel of professional talents in China. The arrival of the Internet era brings an entirely new "revision" to the publishing industry in China. Accordingly, the educational system of publishing major of colleges and universities should changes accordingly. However, there exists some narrow educational thinking in the current education of the publishing major of colleges and universities, which not only goes against training of excellent publishing talents but also becomes an obstacle to the development of the industry. Therefore, active exploration on the cooperative teaching mode of digital publishing courses in the Internet era has become the current research focus of relevant experts and scholars in the industry.

\section{Current Teaching Status Of Digital Publishing COURSES OF COLLEGES AND UNIVERSITIES}

\section{A. Fuzzy Disciplinary Affiliation and Low Professionalism of Talent Training}

The book publishing major firstly set up in Wuhan University in 1983 became the starting point of the education of the editing and publishing major of colleges and universities in China. After more than thirty years, the number of colleges and universities in China that set up the education of the editing and publishing major has reached more than 100. In the setting of the teaching system of colleges and universities in China, the editing and publishing science is not the first-level discipline. Moreover, different schools have their own unique teaching characteristics as well as different teaching strengths and levels. Therefore, different colleges and universities have affiliated the editing and publishing science to different majors based on their own teaching abilities, which causes the problem that the disciplinary affiliation of the editing and publishing major in higher education is quite fuzzy and is lack of clear definition. With the ceaseless rise of the digital publishing industry, demand of professional talents continuously increases. Although some colleges and universities in China have started to set up majors and courses relevant to the digital publishing science on the basis of the existing editing and publishing science, mature teaching system as well as clear disciplinary affiliation has failed to apply to or reflect in the current teaching process of digital publishing courses in colleges and universities. Moreover, the digital publishing major is lack of professionalism of the discipline. Therefore, it has impact and restriction on the quality and level of talent training.

\section{B. Single Course Setting and Lack of Scientificity and Rationalization}

Different from the traditional publishing industry, the digital publishing industry has more industry patterns. Therefore, it requires that personnel need to have rich and diversified knowledge reserves; professional and compound talents become the demand label of talents in the digital publishing industry. At present, under the influence of the 
traditional teaching mode, colleges and universities in China still regard the traditional editing and publishing theoretical theory teaching as the key point and even subject of the teaching and fail to carry out reasonable interlude and fusion with the information technology discipline and even the economy and management discipline in accordance with the characteristics and demands of the digital publishing industry. For example, a part of colleges and universities do not set up network construction discipline, graphic design discipline, marketing management discipline, multimedia technology discipline and other disciplines. As a result, students of the digital publishing major fail to grasp editing skills of new media, carry out business operations skillfully through the information platform or know the market dynamic. Owing to single and unreasonable course setting, the teaching mode of the digital publishing major is inclined to theoretical teaching and is lack of practical teaching and most of the digital publishing courses belong to the cramming teaching system, which are big drawbacks as well as obstacles for the digital publishing teaching.

\section{Insufficient Teaching Equipment Input and Relatively Weak Teacher Resources}

Advancement and frontier of the digital publishing industry itself decides that the digital publishing teaching of colleges and universities needs to be more scientific and advanced. At present, most of colleges and universities in China have insufficient equipment input to education of the digital publishing major. As a result, much of the teaching content is short of assistance of teaching equipment and classroom teaching of teachers is subject to certain limitations so that it cannot ensure the teaching efficiency and quality. In addition, in light of the current situations, colleges and universities in China generally have weak teacher resources of digital publishing courses. The digital publishing major of most of colleges and universities usually shares teacher resources with the traditional editing and publishing major. Although it safeguards the reserve resources of the theoretical knowledge of the traditional publishing teaching, it is lack of resource reserves of the digital media field, the digital publishing field and other fields. Therefore, the number of compound teachers of relevant majors is relatively less. As a result, some colleges and universities even need to second teachers of other colleges and universities to carry on classroom teaching; some other colleges and universities cancel relevant courses that should have set up owing to deficiency of the teacher resources. Such weak teaching hardware conditions and software conditions is difficult to meet the training requirements of the digital publishing talents.

\section{Causes Of Problems Existed In Teaching Of The DigitAl PUBLISHING COURSES}

\section{A. The Talent Educational Idea Is Outdated}

Implementation of teaching activities in colleges and universities is inseparable from the setting of the teaching idea. As to colleges and universities, the teaching idea is the beacon as well as foundation for teaching implementation. When the teaching idea of colleges and universities fails to keep up with the development of the era, it will certainly lead to low quality and level of talent training. With arrival of the Internet era, the information technology further popularizes and develops; any aspect of the digital publishing courses exists larger changes; the digital publishing industry has higher and more requirements for the digital publishing talents. However, the current outdated teaching idea in colleges and universities has a serious impact on the optimization of the talent training plan and also becomes the primary reason that compound professional talents fail to present in quantity.

\section{B. The Education Administrative Department Is Short of the Emphasis on the Development of the Digital Publishing Courses}

Since the setting of the editing and publishing major in colleges and universities in China, the editing and publishing science has been included in the second-level discipline and most of colleges and universities have set the editing and publishing major to the subordinate discipline of the journalism and communication. Many experts and even some scholars in the industry repeatedly appeal colleges and universities to set up the first-level discipline of the publishing science. However, from the latest Catalogue of Undergraduate Program of Colleges and Universities issued by the education administrative department of China, the editing and publishing discipline does not occur any change and it is still a subordinate second-level discipline; the fuzzy disciplinary affiliation still fails to be solved, which lead to more slow and tortuous process of normative development of digital publishing courses in colleges and universities and nonuniform talent training objectives, not to mention safeguard of the talent training quality.

\section{SPECIFIC Optimization MeAsures Of THE CoOperative Teaching Mode OF The Digital Publishing COURSES IN THE INTERNET ERA}

\section{A. Set up Scientific Educational Idea through the New Thinking in the Internet Era}

The rise of the Internet era brings a good platform and even an opportunity to the informationization development of the publishing industry. As to colleges and universities, the promotion of the cooperative teaching quality of the digital publishing courses is inseparable from the optimization and improvement of the teaching idea. The Internet era optimizes the learning style of students, brings very good and convenient conditions and enriches the knowledge acceptance forms of students. Colleges and universities should actively set up the student-oriented teaching mode idea through this series of favorable conditions, scientifically plan teaching methods or teaching content based on the similarities and even differences of students and carry on diversified teaching through benefits of the Internet. In addition, the training quality and level of the digital publishing talent education is inseparable from the optimization of teacher resources. With unceasing popularization of the information era and gradual presentation of new knowledge, teachers of the digital publishing major should continuously promote their own teaching knowledge reserves, insist on lifelong learning, constantly engage in 
advanced studies, widely learn and supplement the knowledge of relevant disciplines, enrich the teaching background, develop teaching thinking, optimize their own teaching ideas and perfect the knowledge structure system. Meanwhile, they should change their roles in the past teaching mode, flip the classroom teaching mode and lay a good foundation for training of professional talents.

\section{B. Innovate the Educational Mode through the Internet Platform}

The arrival of the Internet era is an advantage for the teaching of colleges and universities to some extent. Colleges and universities should change the single face-to-face teaching in the past, broaden the education platform of on-line teaching and continuously transform the combination of these two teaching forms into the new normal of the teaching of the digital publishing courses. The digital publishing major itself is a major closely related to the information technology. Therefore, in setting of teaching and major, they should weed out the old to bring forth the new and constantly carry on independent innovation. They should actively integrate highquality teaching resources of different colleges and universities through the Internet information network, provide more abundant and excellent teaching resources for students with the combination of practical cases of related digital publishing enterprises and transfer great information resources such as the knowledge system, problems sets and so on accumulated in the teaching process to students through the Internet learning platform. In addition, they can make teaching videos as well as multimedia courseware of some compound and interdisciplinary courses, realize the mutual sharing of teaching resources and promote the optimization of the cooperative teaching mode of the digital publishing courses.

\section{Actively Promote the Industry-University-Research Integrated Development by the Industrial Strength}

The Internet era is a transformation and reversal of an era. The digital publishing courses not only have profound theoretical basis but also require stronger practicability. The development of the Internet forms more convenient connection link among colleges and universities, enterprises and research institutes. As to the development of the digital publishing courses, study of theoretical basis is not only the most basic reserve premise but also the integrative condition. Colleges and universities should actively realize the mature development of the industry-university-research integration and further realize the healthy and scientific development of the education of the digital publishing courses through effective assistance of publishing enterprises, research institutes and other organizations. They should actively set practice and training base off campus and attract publishing enterprises to form good cooperative relationship with colleges and universities so that students can take actual practice on the basis of the learning of professional knowledge, promote the actual operational capacity of students and further boost the promotion of the teaching quality by the scientific research strength. They should regularly invite experts and scholars of relevant majors to walk into the classroom of colleges and universities and conduct lectures so that teachers and students can mutually learn more advanced digital publishing teaching knowledge, improve the reserve capacity of the digital publishing knowledge and further promote the perfection of the cooperative teaching mode of the digital publishing courses.

\section{CONCLUSION}

High efficiency and convenience of the information technology not only benefit different fields but also bring a new challenge to traditional industries. On the one hand, the traditional publishing industry enjoys the industrial optimization warfare in the Internet era. On the other hand, it is also faced with new threat. Under the driving of the innovation of the publishing industry, colleges and universities should actively perfect the cooperative teaching mode of the digital publishing courses, improve the teaching level and cultivate more excellent applied and compound talents for the digital publishing industry.

\section{REFERENCES}

[1] Wei Xiurong. New Situation, New Standard and New Image--A Brief Analysis on the Editing Talents in the New Era [A]. Study on Editing Talents--Collected Papers of the 11th Academic Annual Meeting of China Redactological Society [C]. 2015 (11).

[2] Gui Xiaofeng. Promote Emergency and Growth of More Editing Talents--Reflections on Study of Editing Talent Science [J]. Chinese Social Sciences Today [J]. 2015 (09).

[3] Wang Hongchen. Construction of Training Mode of Innovative Editing Talents [A]. Build a Well-Off Society in an All-Around Way: Historic Responsibility of Chinese Scientific and Technological Workers-Collected Papers of 2014 Academic Annual Meeting of China Association for Science (Part II) [C]. 2014.

[4] Lu Jiaqi. The Vocational Qualification System is a Significant Action for Talent Training of the Publishing Majors [A]. Study on Editing Talents--Collected Papers of the 11th Academic Annual Meeting of China Redactological Society [C]. 2015 (07).

[5] Su Aihua, Xiong Chucai, Wang Saiqun. Thinking on Reinforcement of the Editing and Publishing Human Resources Management and Development [A]. Collected Papers of the 4th Academic Seminar of Yong Editors of China S\&T Journal [C]. 2015 (02).

[6] Chen Xiangijao, Wu Limin. Increase the Investment Priority, Do Six Major Works Well and Fully Promote the Development of the Digital Publishing Industry [N]. Chinese Social Sciences Today, 2016.

[7] Zhou Ling, Li Jianjun. Study on the Construction of the GovernmentSociety-University Talent Training Interactive Mechanism [A]. Scientific Support Scientific Development--2015 Expert Forum for Promotion of the Rise of the Central China \& Collected Papers of the 5th Hubei Scientific Papers [C]. 2016

[8] Deng Rong, Li Hongmin. Exploration on Editing Talents and Journal Quality [A]. Reform Innovation and Scientific Development--Collected Papers of the 9th National Core Journal and Journal Internalization and Networking Seminar [C].2014 (02). 